\title{
Metastrongylus spp. infection in a farmed wild boar (Sus scrofa) in Finland
}

\author{
Paula Syrjälä ${ }^{*}$, Antti Oksanen², Outi Hälli ${ }^{3}$, Olli Peltoniemi ${ }^{3}$, Mari Heinonen ${ }^{3}$ \\ From Parasite infections of domestic animals in the Nordic countries - emerging threats and challenges. \\ The 22nd Symposium of the Nordic Committee for Veterinary Scientific Cooperation (NKVet) \\ Helsinki, Finland. 7-9 September 2008
}

\section{Summary}

Metastrongylus spp. (Nematoda, Metastrongylidae) are lung worms of swine and occur worldwide. Species in the family include M. apri, M. pudendotectus, M. asymmetricus, and M. salmi. Earth worms are intermediate hosts and pigs get infected when eating earth worms.

In Finland wild boar farming began in the 1980s and now there are over hundred farms and over 2000 wild boars in different parts of the country. This case report is part of a study aiming to get more information about the diseases that occur in the farmed wild boar population in Finland.

Lungworms were detected in an eight month old farmed wild boar sent for necropsy from a farm situated in eastern Finland. In the group of 25 animals of about the same age, the farmer had noticed poor growth and gait abnormalities. He submitted two euthanized boars (A and B) for necropsy. A routine necropsy was performed and tissue samples were collected for histopathology, bacteriology and parasitology.

The boar A was in a poor nutritional condition. The lungs were slightly mottled, but otherwise normally inflated. Large numbers of white thread like nematodes were detected in the bronchi (Fig. 1.). Bones were soft. In the faecal sample, 7500 EPG Metastrongylus spp. eggs were detected with flotation (Fig. 2.). The boar B was in a moderate nutritional condition. No lung worms were detected. The main pathological diagnosis of both was osteomalacia due to deficiency of mineral feeding. However, the the poor nutritional condition of the boar A infected with lung worms was possibly partly due to the lung worm infection. Four additional faecal samples were sent from remaining boars from the farm and two

${ }^{1}$ Veterinary Bacteriology Research Unit, Finnish Food Safety Authority Evira, Kuopio, Finland

Full list of author information is available at the end of the article

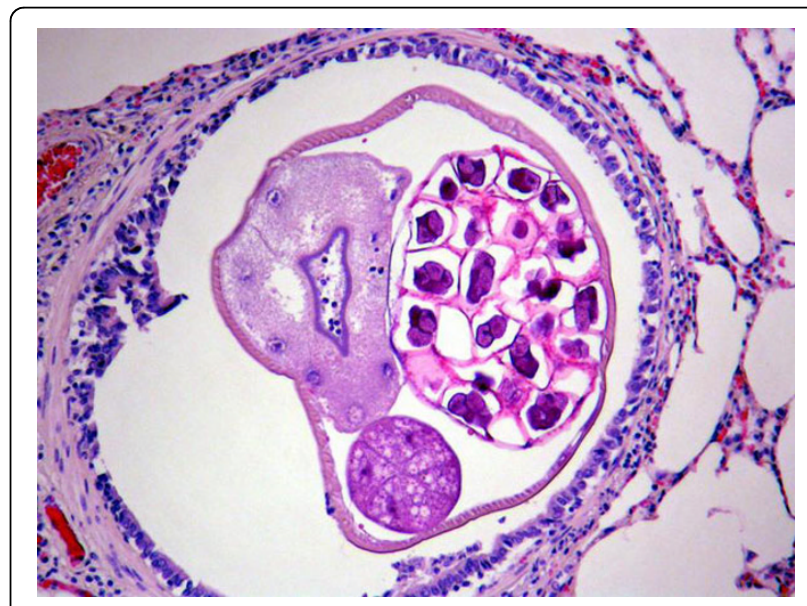

Figure 1 Cross section of Metastrongylus spp. in the lung.

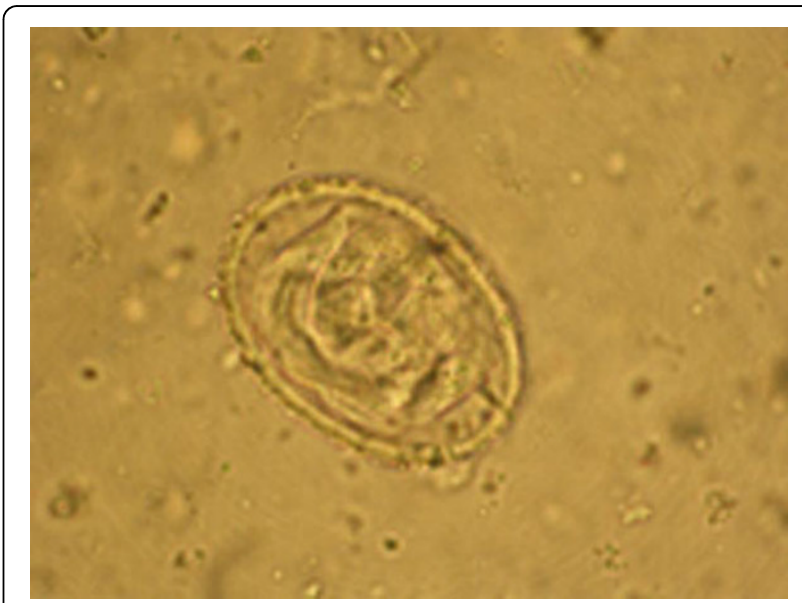

Figure 2 Metastrongylus spp. egg with a larva inside. 
of them were also positive for Metastrongylus spp. eggs (100 and 200 EGP).

In Finland Metastrongylus spp. has occurred sporadically in pigs decades ago in southeastern parts of the country [unpublished, Nikander, [1]. It was not detected in domestic pigs in a large study done in all Nordic countries in 1980's [1]. It was also not found in a study of Danish organic swine herds [2]. In natural wild boar in many countries this parasite is common [3-6]. In the modern pig industry this infection seems to have been disappeared, because there is no contact with the intermediate host, the earth worms. However, in the farmed wild boar, and in situations where pigs are kept outdoors, Metastrongylus spp. should be considered as a possible cause of poor growth and respiratory signs.

\section{Author details}

'Veterinary Bacteriology Research Unit, Finnish Food Safety Authority Evira, Kuopio, Finland. ${ }^{2}$ Fish and Wildlife Health Research Unit, Finnish Food Safety Authority Evira, Oulu, Finland. ${ }^{3}$ Department of Production Animal Health, University of Helsinki, Pohjoinen pikatie 800, 04930 Saarentaus, Finland.

Published: 13 October 2010

\section{References}

1. Roepstorff A, Nilsson O, Oksanen A, Gjerde B, Richter SH, Örtenberg E, Christensson D, Martinsson KB, Bartlett PC, Nansen P, et al: Intestinal parasites in swine in the Nordic countries, prevalence and geographical distribution. Vet Parasitol 1998, 76:305-319.

2. Carstensen $L$, Vaarts M, Roepstorff A: Helminth infections in Danish organic swine herds. Vet Parasitol 2002, 106:253-264.

3. Järvis T, Kapel Ch, Moks E, Talvik H, Mägi E: Helminths of wild boar in the isolated population close to the northern border of its habitat area. Vet Parasitol 2007, 150:366-369.

4. Morita T, Haruta K, Shibata-Haruta A, Kanda E, Imai S, Ike K: Lung worms of wild boars in the western region of Tokyo, Japan. J Vet Med Sci 2007, 69:417-420.

5. de-la-Muela N, Hernandez-de-Lujan S, Ferre I: Helminths of wild boar in Spain. J Wildl Dis 2001, 37:840-843.

6. Barutzki D, Schoierer R, Gothe R: Helminth infections in wild boars in enclosures in southern Germany: species spectrum and infection frequency. Tierarztl Prax 1990, 18:529-534.

doi:10.1186/1751-0147-52-S1-S21

Cite this article as: Syrjälä et al: Metastrongylus spp. infection in a farmed wild boar (Sus scrofa) in Finland. Acta Veterinaria Scandinavica 2010 52(Suppl 1):S21.

\section{Submit your next manuscript to BioMed Central and take full advantage of:}

- Convenient online submission

- Thorough peer review

- No space constraints or color figure charges

- Immediate publication on acceptance

- Inclusion in PubMed, CAS, Scopus and Google Scholar

- Research which is freely available for redistribution

Submit your manuscript at www.biomedcentral.com/submit
C Biomed Central 